\title{
Neutrophil to Lymphocyte Ratio within Clinical Staging of Head and Neck Squamous Cell Carcinoma
}

\author{
Orlena Dharmantary Kartika, Bambang Purwanto, Yussy Afriani Dewi \\ Department of Otorhinolaryngology-Head \& Neck Surgery Faculty of Medicine \\ Universitas Padjadjaran/Dr. Hasan Sadikin General Hospital Bandung, Indonesia
}

Abstract

Background: Neutrophil to lymphocyte ratio (NLR) is one of the inflammatory markers, associated with malignancies progression and metastasis, including head and neck squamous cell carcinoma (HNSCC). Neutrophil to lymphocyte ratio is presenting the activity index of protumor and antitumor. It is easy to perform in daily clinical practice, obtained from blood examination. The aim of this study was to assess the prognostic value of NLR in HNSCC patients, associated with the clinical staging.

Methods: This study was an analytic design to explore the relationship between NLR and clinical staging. The sample was collected from pre-treatment HNSCC patients who came to the Head and Neck Oncology Clinic, Dr. Hasan Sadikin General Hospital. The data consisted of disease history, ENT examination, staging determination, and blood sample examination for NLR count.

Results: In total, data on 92 HNSCC patients were collected. There was a statistically significant association between NLR with clinical staging in HNSCC $(\mathrm{p}<0.001)$. The higher the NLR, the higher the clinical stage, whereas the lower the NLR, (OR14.1; 95\% CI 3.4-59.0).

Conclusions: There is a significant association between NLR with clinical staging in HNSCC. Further study is needed to explore NLR as a prognostic marker in HNSCC patients

Keywords: Clinical staging, head and neck squamous cell carcinoma, neutrophil to lymphocyte ratio

\section{Introduction}

Head and Neck Squamous Cell Carcinoma (HNSCC) is the most common type of the entire head and neck cancers, involving $90 \%$ of the total cases. Every year, there are more than 500,000 new cases of HNSCC worldwide, with 40,000 new cases and 7,890 deaths reported annually in the United States., ${ }^{1,2}$ Indonesian National Cancer Registry places the head and neck carcinoma on the fourth position among the top ten malignancies. ${ }^{3}$ The prevalence of patients with HNSCC in Dr. Hasan Sadikin General Hospital, Bandung in 2010-2014 is $22.3 \%{ }^{4}$

Theinflammatoryresponsehasanimportant role in the development and progression of cancer, and inflammatory indicators may have prognostic means for different types of cancer. The neutrophil-to-lymphocyte ratio (NLR) acts as a free prognostic factor for patients with various types of cancer. An increase in NLR is associated with a decline in Overall Survival (OS) of several solid tumors, including HNSCC. ${ }^{5}$

An increase in NLR indicates an ongoing inflammatory process. The NLR presents the activity index of protumor and antitumor which is easy to do because it is a routine examination in the daily clinical practice, obtained through the peripheral blood examination. ${ }^{6}$ The NLR is easily to perform in daily clinical practice. The aim of this study was to assess the prognostic value of NLR in HNSCC patients, associated with the clinical staging.

\section{Methods}

This study was an analytical research design to assess the NLR as a prognostic factor in HNSCC patients. The inclusion criteria were early and late stage of HNSCC patients with histopathology result was SCC and had never

Correspondence: Orlena Dharmantary Kartika, Department of Otorhinolaryngology-Head \& Neck Surgery Faculty of Medicine Universitas Padjadjaran/Dr. Hasan Sadikin General Hospital, Indonesia, E-mail: dr.orlena@gmail.com 
been given therapy. The exclusion criteria were multiple carcinoma and residual or recurrent HNSCC patients. A cross-sectional study was conducted to include the data from the medical record, involving HNSCC patients. ${ }^{7,8}$ Data on history taking, physical examination, and biopsy were collected. After the positive SCC biopsy results were obtained, other data involving supporting examination were collected, such as Computed Tomography Scan (CT Scan), chest X-ray, and abdominal Ultra Sonography (USG) by the Standard Operating Procedures (SOP). Furthermore, laboratory data were collected from the Clinical Pathology Laboratory for complete blood count (Sysmex Automatic Hematology XT 2000i Analyzer, USA). Neutrophil to lymphocyte ratio (NLR) was used as a marker of subclinical inflammation, and it also presented the activity index of protumor and antitumor. The NLR was calculated by dividing the number of neutrophils percentage over the number of lymphocytes percentage. This study protocol was accepted by the Ethical Committee number is LB.04.01/A05/EC/130/ IV/2018.

The Chi-Square test was used for the statistical analysis and the Fisher Exact test was used for the $2 \times 2$ table. A Receiver Operating Characteristic (ROC) analysis

Table 1 Characteristics of Head and Neck Squamous Cell Carcinoma Patients form Dr. Hasan Sadikin General Hospital

\begin{tabular}{|c|c|c|c|c|}
\hline \multirow[b]{2}{*}{ Subject Characteristics } & \multirow[b]{2}{*}{ Total } & \multicolumn{2}{|c|}{ Clinical Stage } & \multirow[b]{2}{*}{ p-value } \\
\hline & & $\begin{array}{c}\text { Early (I-II) } \\
n=12\end{array}$ & $\begin{array}{c}\text { Advanced (III-IV) } \\
n=80\end{array}$ & \\
\hline \multicolumn{5}{|l|}{ Gender } \\
\hline Male & $81(88.0)$ & $10(83.3)$ & $71(88.8)$ & $0.632 \mathrm{a}$ \\
\hline Female & $11(12.0)$ & $2(16.7)$ & $9(11.3)$ & \\
\hline \multicolumn{5}{|l|}{ Age } \\
\hline Mean \pm SD & $58 \pm 13$ & $59 \pm 17$ & $58 \pm 13$ & $0.819 \mathrm{~b}$ \\
\hline \multicolumn{5}{|l|}{ Carcinoma Location } \\
\hline Larynx & $61(66.3)$ & $9(75.0)$ & $52(65.0)$ & $0.937 \mathrm{c}$ \\
\hline Tongue & $15(16.3)$ & $1(8.3)$ & $14(17.5)$ & \\
\hline Sinonasal & $8(8.7)$ & $1(8.3)$ & $7(8.8)$ & \\
\hline Nasopharynx & $4(4.3)$ & $1(8.3)$ & $3(3.8)$ & \\
\hline Tonsil & $2(2.2)$ & $0(0.0)$ & $2(2.5)$ & \\
\hline Oropharynx & $1(1.1)$ & $0(0.0)$ & $1(1.3)$ & \\
\hline Esophagus & $1(1.1)$ & $0(0.0)$ & $1(1.3)$ & \\
\hline \multicolumn{5}{|l|}{ Histopathology } \\
\hline Moderately differentiated & $44(47.8)$ & $5(41.7)$ & $39(48.8)$ & $0.757 \mathrm{c}$ \\
\hline Well-differentiated & $29(31.5)$ & $5(41.7)$ & $24(30.0)$ & \\
\hline Poorly differentiated & $9(9.8)$ & $1(8.3)$ & $8(10.0)$ & \\
\hline Non keratinizing & $2(2.2)$ & $0(0.0)$ & $2(2.5)$ & \\
\hline Basaloid SCC & $3(3.3)$ & $0(0.0)$ & $3(3.8)$ & \\
\hline $\begin{array}{l}\text { Non keratinizing } \\
\text { moderately differentiated }\end{array}$ & $2(2.2)$ & $0(0.0)$ & $2(2.5)$ & \\
\hline $\begin{array}{l}\text { Non-keratinizing poorly } \\
\text { differentiated }\end{array}$ & $2(2.2)$ & $1(8.3)$ & $1(1.3)$ & \\
\hline Carsinoma in situ & $1(1.1)$ & $0(0.0)$ & $1(1.3)$ & \\
\hline
\end{tabular}

Note: The Chi-Square test was used for the statistical analysis of this study. The analysis was used afisher exact test, ${ }^{\mathrm{b}}$ unpaired t-test, ${ }^{\mathrm{c}} \mathrm{chi}$ square test, ${ }^{*}$ significant at $\mathrm{p}<0,05$ 


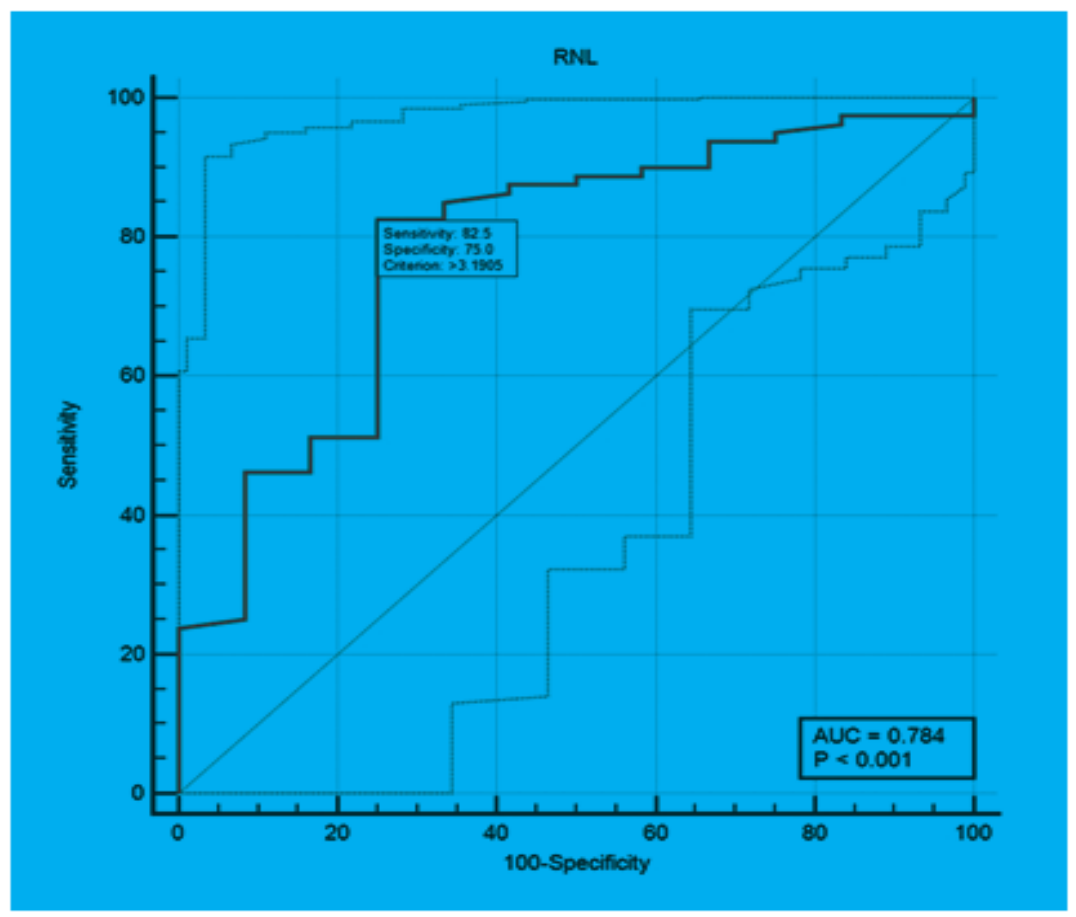

\section{Figure The NLR Cut off Point Based on ROC Curve Analysis}

was performed before the Chi-Square test was done to find an optimal cut off point of the NLR. The significance criteria used was when $p$-values $<0.05$. The data obtained were recorded and then processed through the Statistical Package for the Social Sciences (SPSS) version 21.0 program for Windows.

\section{Results}

In total, 92 data of HNSCC patients were collected, consisting of HNSCC in the early clinical stage $(n=12)$ and in advanced clinical stage $(n=80)$. The majority of HNSS patients were males (88.0\%). The overall characteristics of the patients in this study were shown in
Table 1.

The value of the NLR was determined based on literature, while the cutoff point of the NLR was obtained through the ROC curve analysis. NLR cutoff points based on the ROC curve analysis were 3.2 with area under the curve (AUC) value of 0.784 , a sensitivity of $82.5 \%$ and specificity of $75.0 \%$ (Figure). Based on the cutoff point value, NLR was categorized as low if NLR was $<3.2$ and high if NLR was $>3.2$.

There was a significant difference between NLR and clinical stages in HNSCC patients ( $p<0.001$ ). The direction of the relationship shown was positive, meaning that the higher the NLR, the higher the clinical stage in patients with HNSCC; whereas the lower the NLR, the lower the clinical stage. The Odds

Table 2 The Relationship between NLR and Clinical Staging

\begin{tabular}{|c|c|c|c|c|c|}
\hline \multirow[b]{2}{*}{ Variable } & \multirow[b]{2}{*}{ Total } & \multicolumn{2}{|c|}{ Clinical Stage } & \multirow[b]{2}{*}{ p-value } & \multirow[b]{2}{*}{ OR $(95 \% C I)$} \\
\hline & & $\begin{array}{c}\text { Early (I-II) } \\
n=12\end{array}$ & $\begin{array}{c}\text { Advanced (III-IV) } \\
\mathbf{n}=\mathbf{8 0}\end{array}$ & & \\
\hline \multicolumn{6}{|l|}{ NLR } \\
\hline Low & $23(25.0)$ & $9(75.0)$ & $14(17.5)$ & $<0.001$ & $14.1(3.4-59.0)$ \\
\hline High & $69(75.0)$ & $3(25.0)$ & $66(82.5)$ & & \\
\hline
\end{tabular}

Note: Low NLR was $<3.2$ and High NLR was $>3.2$ 
Ratio (OR) of this study was 14.1, meaning that patients who had a high NLR in HNSCC had a 14.1 higher risk in being in the advanced clinical stage compared to patients with a low NLR ratio.

\section{Discussions}

This study has explored the NLR as a prognostic marker in HNSCC patients. Most of our patients were males $(88 \%)$, similar to study in Bulgaria ${ }^{11}$ with male and female ratio of 3.23:1. Another study in India ${ }^{12}$ also reports that HNSCC is more common in males than females, with an oral SCC and oropharyngeal SCC ratio based on gender about 1.5:1 and 2.8: 1, respectively. Moreover, a study in Pakistan $^{12}$ shows head and neck carcinoma happens in $21 \%$ of males and $11 \%$ of females. This is in line with research in other places in Indonesia ${ }^{4,13}$, reporting that most of HNSCC patients are males.

The risks of head and neck carcinoma increase with age, and the majority occur at the age of 50 or older. Our study has shown that the age of HNCSS patients in early is $59+17$ compared to the advanced stage which is 58 +13 . Although the difference in both clinicalstage is not significantly different, there is a trend that in the advanced stage HNCSS is younger, similar to study that shows more than $50 \%$ cases of head and neck carcinoma occur at the age of $>60$, and $28 \%$ occurs at the age of $>70$. Head and neck carcinoma also occur in middle-aged patients (aged 46-55). ${ }^{4}$

Interestingly, most carcinomas in this study $(66.3 \%)$ are located in the larynx, and those have come at an advanced stage. This was in accordance with the result of other studies. ${ }^{11}$

The most histopathological findings in our study were moderate differentiation $(47.8 \%)$, whereas carcinoma in situ is the least histopathological finding. This contrasts with the results of a study conducted in other places in Indonesia, that most of the HNSCC patients came with a high differentiation grade or in bad differentiation), ${ }^{14}$ or in opposite with the result in the National Referral Cancer Hospital $^{13}$, that the most differentiation from HNSCC patients admitted in the hospital is the good differentiation. ${ }^{13}$ The difference in histopathological findings may very much depend on the various factors and need to be further explored.

Meaningful results between NLR and clinical stage of HNSCC ( $p<0.001)$ in our study shows that there is a positive relationship between NLR and clinical stage of the disease; the higher the NLR, the higher the clinical stage of HNSCC, whereas the lower the NLR, the lower the clinical stage of HNSCC. The odds ratio (OR) in this study is 14.1; the patients with a high NLR who is suffering from HNSCC have a 14.1 times possible to have an advanced clinical stage compared to patients with a low NLR. A systematic review by Guthrie et al. ${ }^{15}$ have shown that the neutrophil-lymphocyte ratio has an independent prognostic value on tumor clinical staging.

The limitations of this study are that the data on co-morbidity in HNSCC patients such as other metabolic diseases or chronic inflammation is lacking, as this condition may have a high value of NLR, so the confounding factor that may present could not be further assessed. Therefore, further study is needed to compare NLR in HNSCC patients with or without morbidity and prospective follow-up design study is needed to compare the NLR value pre and post-therapy among HNSCC patients.

As a conclusion, NLR can be used as the prognostic marker for the clinical stage in HNSCC patients; the higher the NLR, the higher the clinical stage, with higher values is correlated with poor outcomes.

\section{References}

1. Timmerman A. Neck ultrasound as a diagnostic method of cervical lymph node metastasis in patients with head and neck squamous cell carcinoma [thesis]. Orebro, Sweden: School of Health and Medical Sciences Department of Clinical Medicine Orebro Universitet; 2017.

2. Marur S, Forastiere AA. Head and neck squamous cell carcinoma: update on epidemiology, diagnosis, and treatment. Mayo Clinic Proc. 2016;91(3):386-96.

3. Arifianto A. Hubungan ekspresi epidermal growth factor receptor dengan stadium klinis karsinoma sel skuamosa kepala leher [thesis]. Bandung: Universitas Padjadjaran; 2015.

4. Sabirin MSM, Permana AD, Soeseno B. Epidemiologi penderita tumor ganas kepala leher di Departemen Telinga Hidung Tenggorokan-Kepala Leher Rumah Sakit Dr. Hasan Sadikin Bandung Indonesia, Periode 2010-2014. Tunas Medika Jurnal Kedokteran \& Kesehatan. 2016;3(1):1-6.

5. Salim DK, Mutlu H, Eryilmaz MK, Salim O, Musri FY, Tural D, et al. Neutrophil to lymphocyte ratio is an independent prognostic factor in patients with recurrent 
or metastatic head and neck squamous cell cancer. Mol Clin Oncol. 2015;3(4):839-42.

6. Yu B, Li Z, Zheng Q, Luo Z, Li J, Zhou Y, Wang L, He C, Shi F, Wang R. Prognostic value of neutrophil to lymphocyte ratio in patients with nasopharyngeal carcinoma: A Metaanalysis. Biomed Res. 2017;28(3):137882.

7. Agresti A. An introduction to categorical data analysis. 3rd Ed. New Jersey: John Wiley and Sons; 2018. p. 207-45.

8. Sastroasmoro S, Ismael S. Dasar-dasar metodologi penelitian klinis. 5th Ed. Jakarta: Sagung Seto; 2014. p. 130-43, 366.

9. Field AP. Discovering statistics using SPSS: (And sex and drugs and rock ' $n$ ' roll). $3^{\text {rd }}$ Ed. London: SAGE Publication Ltd; 2011. p. 128-34.

10. Levy PS, Lemeshow S. Sampling of population, methods, and application. $4^{\text {th }}$ Ed. New York: John Wiley and Sons; 2011. p. 291-308.

11. Stoyanov GS, Kitanova M, Dzhenkov DL,
Ghenev P, Sapundzhiev N. Demographics of head and neck cancer patients: A single institution experience. Cureus. 2017;9(7):e1418.

12. Joshi P, Dutta S, Chaturvedi P, Nair S. Head and neck cancers in developing countries. Rambam Maimonides Med J. 2014;5(2):e0009.

13. To'bungan $\mathrm{N}$, A'liyah $\mathrm{SH}$, Wijayanti $\mathrm{N}$, Fachiroh J. Epidemiologi, stadium, dan derajat diferensiasi kanker kepala dan leher. Biogenesis. 2015;3(1):47-52.

14. Ayuni L. Profil penderita karsinoma sel Skuamosa kepala dan leher (KSSKL) di RSUP Haji Adam Malik Tahun 20122016 [minor thesis]. Medan: Universitas Sumatera Utara; 2017.

15. Guthrie GJ, Charles KA, Roxburgh CS, Horgan PG, McMillan DC, Clarke SJ. The systemic inflammation-based neutrophillymphocyte ratio: experience in patients with cancer. Crit Rev Oncol Hematol. 2013;88(1):218-30. 